\title{
ЗАСТОСУВАННЯ PRP TA PRF TЕХНОЛОГІЙ У ПІДГОТОВЦІ ДО ВИКОНАННЯ РАДІОЧАСТОТНОЇ АБЛЯЦІЇ ВЕН У ХВОРИХ НА ВАРИКОЗНУ ХВОРОБУ НИЖНІХ КІНЦІВОК, УСКЛАДНЕНУ ТРОФІЧНОЮ ВИРАЗКОЮ
}

\author{
○В. Б. Гощинський, Б. О. Мігенько, Ю. Ю. Свідерський \\ Тернопільський національний медичний університет імені І. Я. Горбачевського МОЗ України
}

РЕзюмЕ. Застосування малоінвазивних технологій $є$ сучасним напрямком у лікуванні варикозної хвороби нижніх кінцівок. Однак показання до виконання цих операцій на тлі трофічних виразок є обмеженими.

Мета - дати клінічне обґрунтування застосуванню PRP, PRF технологій для лікування трофічної виразки у хворих із хронічною венозною недостатністю в стадії декомпенсації з метою їх підготовки до наступного виконання радіочастотної абляції вен.

Матеріал і методи. Проведено клінічне обґрунтування застосування PRP та PRF для лікування трофічної виразки у 35 хворих. Контрольною групою були 30 хворих, яким місцево застосовували метилурацилову або актовегінову мазі. Перед лікуванням хворих виконували УзД для встановлення особливостей гемодинаміки у поверхневій та глибокій венозній системі, локалізації перфорантних вен. Усім хворим проведена оцінка стану трофічних виразок на момент лікування та в процесі його виконання із застосуванням системи MEASURE.

Результати. Застосування PRP та PRF для лікування трофічної виразки суттєво посилює процеси регенерації в трофічній виразці, про що свідчить зменшення термінів появи грануляційної тканини, крайової епітелізації.

Також у пацієнтів, порівняно з контрольною групою хворих, зменшилася площа і глибина ранових дефектів на 23,1 \%, 37,4 \% і 79,9 \% відповідно, на 5-6, 8-9, 12-14 добу, порівняно з вихідними даними. До 8 дня у більшості хворих відмічається зміна характеру цитограм на регенераторно-запальний тип. Зникають детрит, мікробні тіла. Характерною ознакою є виражена епітелізація. У 24 пацієнтів трофічна виразка загоїлась. Іншим 11 хворим виконана аутодермопластика трофічної виразки під час проведення РЧА вен. Середній день передопераційної підготовки хворих із трофічними виразками, в яких була застосована PRP та PRF технологія, склав $(7,8 \pm 4,6)$ доби, проти $(14,6 \pm 3,7)$ доби в контрольній групі. Це дало можливість провести повноцінну РЧА варикозно трансформованих вен із додатковою ліквідацією горизонтального рефлюксу в ділянці трофічних змін шляхом застосування склеротерапії неспроможних перфорантних вен під УЗ-навігацією.

Висновки. 1. Застосування технології PRP та PRF активізує процеси регенерації в хронічній трофічній виразці, що дозволяє скоротити передопераційну підготовку хворих.

2. PRP та PRF технологія лікування трофічних виразок у комбінації з малотравматичними операціями (РЧА та склеротерапія) $€$ перспективним напрямком лікування хворих із варикозною хворобою нижніх кінцівок у стадії декомпенсації.

КЛючовІ СлОВА: варикозна хвороба; трофічні виразки; PRP та PRF технології.

Вступ. Варикозна хвороба $\epsilon$ найпоширенішим захворюванням судин нижніх кінцівок. Частота її серед населення коливається від 9,3 до $25 \%$ В Європі це захворювання діагностують у $10 \%$ дорослого населення. Щорічне збільшення захворюваності на варикозну хворобу нижніх кінцівок (ВХНК) сягає 2,5\%. ВХНК і хронічна венозна недостатність (ХВН) $є$ важливою соціально-економічною проблемою, оскільки в останні роки наявна тенденція до зростання захворюваності серед осіб працездатного віку, збільшення кількості ускладнених форм і, як наслідок - до формування стійкої непрацездатності $[5,12]$.

Традиційним методом лікування ВХНК впродовж багатьох років $\epsilon$ класична сафенектомія. Впродовж останнього десятиріччя почали активно впроваджуватись нові технології лікування BXHK, зокрема лазерна та радіочастотна абляція вен (РЧА), які $\epsilon$ малотравматичними і забезпечують гарний косметичний ефект $[4,7,9,11]$. РЧА, завдяки відносній простоті технічного виконан- ня, добрим функціональним результатам, завойовує все більше прихильників у США та Європі [6]. Однак, не дивлячись на широке використання РЧА в клінічній практиці, залишається ряд нез'ясованих питань. Вкрай обмежені дані про використання РЧА у хворих на тлі трофічних виразок (у стадії декомпенсації ВХНК), тому відсутні показання до застосування РЧА у цієї категорії хворих, а також не розроблена технологія ії виконання та аналіз можливих ускладнень. Слід наголосити на питанні індивідуального підходу до вибору методики виконання РЧА залежно від клініко-анатомічних та ультразвукових даних у хворих із декомпенсованою формою ВХНК. 3 наукового та практичного поглядів цікавою $\epsilon$ відповідь на питання щодо ефективності застосування інших сучасних малоінвазивних технологій у поєднані з РЧА для лікування хворих із ВХНК у стадії декомпенсації. Також важливим $\epsilon$ питання розробки ефективних методів прискорення загоєння трофічних виразок венозного ґе- 
Огляди літератури, оригінальні дослідження, погляд на проблему, випадок з практики, короткі повідомлення незу з метою зменшення терміну передопераційної підготовки $[2,3,10]$.

Мета - дати клінічне обґрунтування застосуванню PRP, PRF технологій для лікування трофічної виразки у хворих із хронічною венозною недостатністю в стадії декомпенсації з метою їх підготовки до наступного виконання радіочастотної абляції вен.

Матеріали та методи дослідження. Під спостереженням перебували 65 хворих із варикозною хворобою нижніх кінцівок у стадії декомпенсації (С 6 за класифікацією СЕАР). Жінок було 44, чоловіків - 21, вік хворих становив $(45 \pm 4,6)$ років. Розміри трофічної виразки були з 2,5×1,5 см до 8,5×7,5 см, тривалість лікування в середньому складала до 6 місяців. При цьому, згідно з класифікацією Е. Я. Фісталь, в основу якої покладена глибина ураження виразковим процесом тканини сегмента, переважна більшість хворих (48; 73,8 \%) мали II ступінь захворювання. Згідно з цією класифікацією, до першого анатомічного шару належить епідерміс, до другого шару - дерма, підшкірна жирова клітковина і/або фіброзна тканина, до третього шару - м'язи, сухожилля й судинно-нервові пучки, до четвертого шару - кістково-суглобові структури [1]. У 35 хворих трофічну виразку лікували за методикою PRP та PRF терапії, а у 30 пацієнтів для стимуляції процесу регенерації в трофічних виразках місцево застосовували метилурацилову або актовегінову мазі.

Усім хворим була виконана ультразвукова діагностика для встановлення флебогемодинамічних порушень у кінцівці. УЗД венозної системи нижніх кінцівок виконували на апараті Vivid 3 (Дженерал Електрик, США) з датчиком частотою 5-10 МГц та відповідним стандартним пакетом програмного забезпечення вказаної фірми для дослідження венозної системи. Пацієнтів обстежували у другій половині дня у вертикальному та горизонтальному положеннях. Під час ультразвукового дослідження оцінювали наявність кровотоку у венах, діаметри та форми просвіту вен, їх деформацію та мішкоподібну трансформацію, товщину стінок, однорідність, еластичність клапанів, їх функцію під час навантажувальних гідростатичних проб, наявність рефлюксу крові, тривалість ретроградного потоку по венозних магістралях, а також його поширення на анатомічні сегменти, стан сафено-феморального та сафенопоплітеального гирл. Особливу увагу приділяли локалізації перфорантних вен, визначенню їх діаметра та тривалості рефлюксу венозної крові в них.

Усім хворим проведена оцінка стану трофічних виразок на момент лікування PRP та PRF та в процесі його виконання із застосуванням системи MEASURE. Вона включала вимірювання довжини,

ширини, глибини, площі виразки, кількість ексудату та оцінку його характеру, зовнішній вигляд ранового ложа, больові відчуття, наявність або відсутність некрозу тканин, стан країв рани та навколишніх тканин. За допомогою методу копіювання прозорою плівкою визначали площу трофічної виразки на початку лікування та після зняття вакуумної пов'язки. Вимірювання швидкості епітелізації проводили методом планіметрії виразок до початку PRP і PRF, на 4 та 8 дні після виконання процедур. Швидкість епітелізації виразкового дефекту визначали за формулою

$$
\mathrm{S}-\mathrm{Sn} / \mathrm{t}
$$

де S - початкова площа виразки до лікування, Sn площа при наступному вимірюванні, t - число днів між вимірюваннями. Динаміку ранового процесу визначали за допомогою цитологічного аналізу клітинного складу виразкового дефекту методом відбитків. Для оцінки вираженості дегенеративних та регенеративних процесів у виразці використали регенеративно-дегенеративний індекс. Цитологічні показники були вивчені на момент госпіталізації хворих у стаціонар та на 5-6, 8-9, 12-14 дні під час лікування трофічних виразок.

Інтенсивність больового синдрому визначали за Цифровою рейтинговою шкалою (Numerical Rating Scale, NRS). Оцінку тяжкості венозних захворювань оцінювали за шкалою VCSS.

Плазму, збагачену факторами росту (PRGF®ENDORET®), готували згідно з протоколом Інституту біотехнологій ВTI (Іспанія). Пацієнтам проводили забір 36 мл крові у 4 пробірки ємністю 9 мл, що містили 3,8 \% цитрат натрію. Кров центрифугували (центрифуга BTI System IV) зі швидкістю 580 g упродовж 8 хв, отриману плазму розділяли на фракції (F1 та F2). Для ін'єкції забирали фракцію F2 по 2 мл із кожної пробірки. Потім в асептичних умовах маніпуляційної виконували підшкірні ін'єкції по периферії трофічної виразки, відступивши до 1 см від ії краю з відстанню між вколюваннями 2 см. Одночасно поверхню виразки закривали плазматичною мембраною, збагаченою факторами росту, яка була приготовлена із F2. Залежно від площі виразки використовували одну або дві плазматичні мембрани (рис. 1, 2).

Для ліквідації вертикального скиду використовували РЧА за методикою VNUS - Closure FAST, за допомогою високотехнологічного апарату COVIDIEN фірми Medtronics.

Результати й обговорення. Вже після одного сеансу PRP та PRF відзначали зменшення болю В ділянці трофічної виразки $3(5,0 \pm 0,2)$ до $(1,4 \pm 0,6)$ балів, нормалізацію температури тіла, сну і апетиту. Також у пацієнтів зменшилися площа і глибина ранових дефектів на 23,1\%, 37,4 \% і 79,9 \% на 5-6, 8-9, 12-14 доби відповідно, порів- 
Огляди літератури, оригінальні дослідження, погляд на проблему, випадок з практики, короткі повідомлення
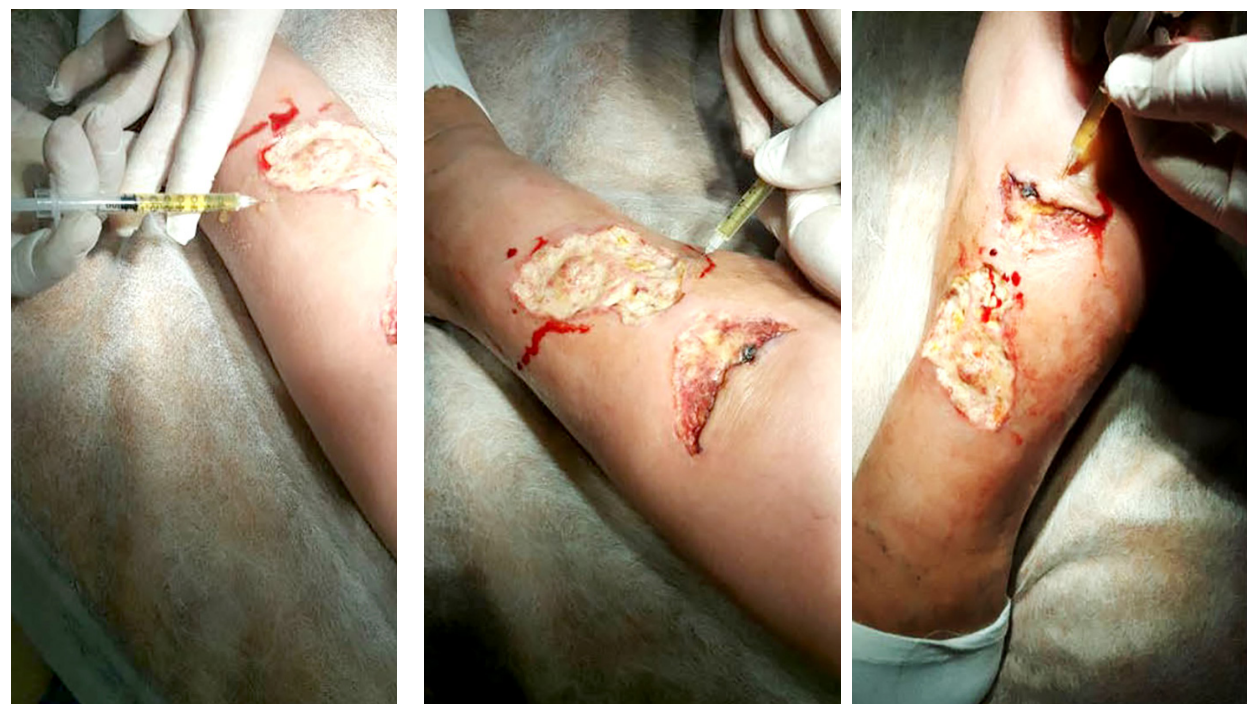

Рис. 1. Хворий С. Ін'єкція плазми по периферії виразки.
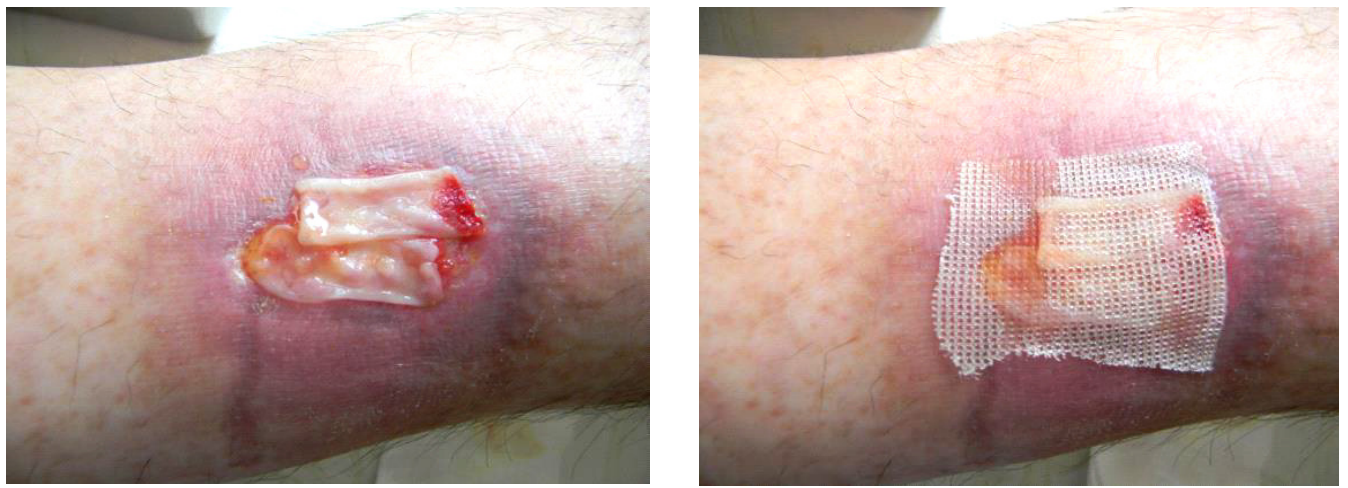

Рис. 2. Хворий С. Закриття поверхні трофічної виразки плазматичною мембраною.

няно з вихідними даними. Також у більшості пацієнтів відмічене зменшення перифокального набряку та гіперемії шкіри навколо рани вже на третю добу лікування.

Відмічено, що середній термін появи грануляційної тканини у цих пацієнтів був на $(5,74 \pm$ $1,65)$ добу, а початок крайової епітелізації - на $(6,2 \pm 1,44)$ добу (у контрольній групі хворих - на $(8,73 \pm 1,4)$ та $(10,25 \pm 1,7)$ добу $(p<0,05))$. Результати цитологічних досліджень показали, що застосування вищезгаданих технологій привело до зменшення в мазках-відбитках ран кількості клітин, характерних для гострої фази запалення (нейтрофілів, лімфоцитів, моноцитів) і збільшення кількості клітин, відповідальних за репаративні процеси (макрофагів, фібробластів). Уже на 2-3 добу в хворих відзначено зменшення вмісту нейтрофілів і лімфоцитів, на 4-5 добу-всіх клітин запалення. Це відповідає переходу дегенеративно-запального типу цитограм до запально-регенеративного типу. До 8 дня у більшості хворих відмічається зміна характеру цитограм на регенераторно-за- пальний тип. Зникають детрит, мікробні тіла. Характерною ознакою $\epsilon$ виражена епітелізація. У 24 пацієнтів трофічна виразка загоїлась. Іншим 11 хворим виконана аутодермопластика трофічної виразки під час проведення РЧА вен. При цьому тяжкість перебігу венозного захворювання за шкалою VCSS в основній групі зменшилась 3 $(12 \pm 0,2)$ балів до $(5 \pm 0,3)$, в контрольній групі цей показник склав $(8 \pm 0,4)$ бали.

Середній день передопераційної підготовки хворих із трофічними виразками, у яких була застосована технологія PRP та PRF, склав $(7,8 \pm 4,6)$ доби, проти $(14,6 \pm 3,7)$ доби в контрольній групі хворих. Це дозволило провести повноцінну РЧА варикозно трансформованих вен із додатковою ліквідацією горизонтального рефлюксу в ділянці трофічних змін шляхом застосування склеротерапії неспроможних перфорантних вен під УЗД навігацією.

Висновки. 1. Застосування технології PRP та PRF активізує процеси регенерації в хронічній трофічній виразці, що дозволяє скоротити передопераційну підготовку хворих. 
Огляди літератури, оригінальні дослідження, погляд на проблему, випадок з практики, короткі повідомлення

2. PRP та PRF технологія лікування трофічних виразок у комбінації з малотравматичними операціями (РЧА та склеротерапія) $\epsilon$ перспективним напрямком лікування хворих із варикозною хворобою нижніх кінцівок у стадії декомпенсації.

\section{ЛІТЕРАТУРА}

1. Классификация глубины поражения тканей при трофических язвах / Э. Я. Фисталь, А. Г. Попандопуло, В. В. Ареф'єв, В. В. Солошенко // Клінічна хірургія. 2007. - № 4. - C. 42-45.

2. Оцінка комплексного лікування хронічної венозної недостатності в стадії трофічних виразок із застосуванням оксиду азоту й аплікаційних сорбентів / О. О. Біляєва, М. І. Балінська, Л. І. Уланович, Ф. А. Устинченко, А.О. Базишен // Харківська хірургічна школа. 2015. - №6(75). - С. 144-147.

3. Чур Н. Н. Современный взгляд на лечение трофических язв нижних конечностей венозного генеза / Н. Н. Чур, И. Н. Гришин, С. Н. Чур // Новости хирургии. 2018. - T. 16, № 2. - С. 139-148.

4. Almeida J. I. Radio frequency endovenous Closure FAST versus laser ablation for the treatment of great saphenous reflux: a multicenter, single-blinded, randomizedstudy (RECOVERY study) / J. I. Almeida // J. Vasc. Interv. Radiol. - 2009. - Vol. 20 (6). - P. 752-759.

5. Beale R. J. Treatment options for primary varicose veins - a review / R. J. Beale, M. J. Gough // European Journal of Vascular Surgery. - 2005. - No. 30 (1). - P. 83-95.

6 . Bootun R. The advent of non-thermal, non-tumescent techniques for treatment of varicos eveins / R. Boo-
Перспективи подальших досліджень. На підставі результатів аналізу малоінвазивних оперативних втручань на тлі декомпенсованої форми хронічної венозної недостатності розробити алгоритм їх застосування залежно від УЗД, клінічної картини та стану трофічної виразки. tun, T. R. Lane, A. H. Davies // Phlebology. -2015. - No. 30.P. 5-10.

7. Jacquet R. Treatment of lower limb varicos eveinsin 2015: Thepresent and the future / R. Jacquet // Ann. Dermatol. Venereol. - 2015. - No. 142. - P. 483-492.

8. Joh J. H. Consensus for the treatment of varicose vein with radio frequency ablation / J. H. Joh // Vasc. Specialist Int. - 2014. - No. 30. - P. 105-112.

9. Hamdan A. Management of varicos eveins and venous insufficiency / A. Hamdan // JAMA. - 2012. No. 308 (24). - P. 2612-2621.

10. Howard D. P. The role of superficial venous surgery in the management of venous ulcers. System aticre view / D. P. Howard // European Journal of Vascular and Endovascular Surgery. - 2008. - No. 36 (4). - P. 458-465.

11. A cost effectiveness analysis of surgery, endothermal ablation, ultrasound-guided foam sclerotherapy and compressions tockings for symptomatic varicose veins / G. Marsden, M. Perry, A. Bradbury [et al.] // Eur. J. Vasc. and Endovasc. Surg. - 2015. - No. 50 (6). - P. 794-801.

12. Sarah Onida. Varicose veins and their management / Sarah Onida, Tristan R. A. Lane, Alun H. Davies // Vasc. Surgery (II). - 2013. - Vol. 31 (5). - P. 211-217.

\section{REFERENCES}

1. Fistal, Ye., Papadopoulos, A., Arefyev, V., \& Soloshenko, V. (2007). Klassifikatsiya glubiny porazheniya tkaney pri troficheskikh yazvakh [Classification of the depth of tissue lesions in trophic ulcers]. Klinichna khirurhiia - Clinical Surgery, 4, 42-45 [in Russian].

2. Biliaieva, O., Balinska, M., Ulanovich, I., Ustinchenko, F., \& Bazishen, A. (2015). Otsinka kompleksnoho likuvannia khronichnoi venoznoi nedostatnosti $v$ stadii trofichnykh vyrazok iz zastosuvanniam oksydu azotu i aplikatsiinykh sorbentiv [Evaluation of the comprehensive treatment of chronic venous insufficiency in the stage of venous ulcers using nitrogen oxide and application sorbents]. Kharkivska khirurhichna shkola - Kharkiv Surgical School, 6 (75), 144147 [in Ukrainian].

3. Chur, N.N., Grishin, I.N., \& Chur, S.N. (2018). Sovremennyy vzglyad na lecheniye troficheskikh yazv nizhnikh konechnostey venoznogo geneza [Modern view on treatment of trophic ulcers of the lower limbs of venous genesis]. Novosti khirurgii - News of Surgery, 2 (16), 139148 [in Russian].

4. Almeida, J.I. (2009). Radiofrequency endovenous Closure FAST versus laser ablation for the treatment of great saphenous reflux: a multicenter, single-blinded, randomized study (RECOVERY study). J. Vasc. Interv. Radiol., $20(6), 752-759$.

5. Beale, R.J., Beale, R.J., \& Gough, M.J. (2005). Treatment options for primary varicose veins - a review. European Journal of Vascular Surgery, 30 (1), 83-95.

6. Bootun, R., Lane, T.R., \& Davies, A.H. (2015). The advent of non-thermal, non-tumescent techniques for treatment of varicose veins. Phlebology, 30, 5-10.

7. Hamdan, A. (2012). Management of varicose veins and venous insufficiency. JAMA, 308 (24), 2612-2621.

8. Howard, D.P. (2008). The role of superficial venous surgery in the management of venous ulcers. Systematic review. European Journal of Vascular end Endovascular Surgery, 36 (4), 458-465.

9. Jacquet, R. (2015). Treatment of lower limb varicose veins in 2015: The present and the future. Ann. Dermatol. Venereol., 142, 483-492. 
Огляди літератури, оригінальні дослідження, погляд на проблему, випадок з практики, короткі повідомлення

10. Joh, J.H. (2014). Consensus for the treatment of varicose vein with radiofrequency ablation. Vasc. Specialist Int., 30, 105-112.

11. Marsden, G., Perry, M., \& Bradbury, A. (2015). A cost effectiveness analysis of surgery, endothermal ablation, ultrasound-guided foam sclerotherapy and compres- sion stockings for symptomatic varicose veins. Eur. J. Vasc. and Endovasc. Surg., 50 (6), 794-801.

12. Sarah Onida, Tristan R.A. Lane, \& Alun H. Davies (2013). Varicose veins and their management. Vasc. Surgery., 31 (5), 211-217.

\title{
ПРИМЕНЕНИЕ РRР И РRF ТЕХНОЛОГИЙ В ПОДГОТОВКЕ К ВЫПОЛНЕНИЮ РАДИОЧАСТОТНОЙ АБЛЯЦИИ ВЕН У БОЛЬНЫХ ВАРИКОЗНОЙ БОЛЕЗНЬЮ НИЖНИХ КОНЕЧНОСТЕЙ, ОСЛОЖНЕННОЙ ТРОФИЧЕСКОЙ ЯЗВОЙ
}

\author{
๑В. Б. Гощинский, Б. О. Мигенько, Ю. Ю. Свидерский
}

Тернопольский национальный медицинский университет имени И. Я. Горбачевского МОз Украины

РЕзюмЕ. Применение малоинвазивных технологий является современным направлением в лечении варикозной болезни нижних конечностей. Однако показания к выполнению этих операций на фоне трофических язв ограничены.

Цель - дать клиническое обоснование применению PRP, PRF технологий для лечения трофической язвы у больных с хронической венозной недостаточностью в стадии декомпенсации с целью их подготовки к последующему выполнению радиочастотной абляции вен.

Материал и методы. Проведено клиническое обоснование применения PRP и PRF для лечения трофической язвы у 35 больных. Контрольной группой были 30 больных, которым местно применяли метилурациловую или актовегиновую мази. Перед лечением больных выполняли УЗИ для установления особенностей гемодинамики в поверхностной и глубокой венозной системе, локализации перфорантных вен. Всем больным проведена оценка состояния трофических язв на момент лечения и в процессе его выполнения с применением системы MEASURE.

Результаты. Применение PRP и PRF для лечения трофической язвы существенно усиливает процессы регенерации в трофической язве, о чем свидетельствует уменьшение сроков появления грануляционной ткани, краевой эпитализации.

Также у пациентов, по сравнению с контрольной группой больных, уменьшилась площадь и глубина раневых дефектов на 23,1 \%, 37,4 \% и 79,9 \% соответственно, на 5-6, 8-9, 12-14 сутки, по сравнению с исходными данными. До 8 дня у большинства больных отмечается изменение характера цитограмм на регенераторно-воспалительный тип. Исчезают детрит, микробные тела. Характерным признаком является выраженная эпителизация. У 24 пациентов трофическая язва зажила. Другим 11 больным выполнена аутодермопластика трофической язвы при проведении РЧА вен. Средний день предоперационной подготовки больных с трофическими язвами, у которых была применена PRP и PRF технология, составил $(7,8 \pm 4,6)$ суток, против $(14,6 \pm 3,7)$ суток в контрольной группе. Это дало возможность провести полноценную РЧА варикозно трансформированных вен с дополнительной ликвидацией горизонтального рефлюкса в области трофических изменений путем применения склеротерапии несостоятельных перфорантных вен под УЗ-навигацией.

Выводы. 1. Применение технологии PRP и PRF активизирует процессы регенерации в хронической трофической язве, что позволяет сократить предоперационную подготовку больных.

2. PRP и PRF технология лечения трофических язв в сочетании с малотравматичными операциями (РчА и склеротерапия) является перспективным направлением лечения больных с варикозной болезнью нижних конечностей в стадии декомпенсации.

КЛЮчЕВЫЕ СЛОВА: варикозная болезнь; трофические язвы; PRP и PRF технологии.

\section{APPLICATION OF PRP AND PRF TECHNOLOGIES IN PREPARATION FOR THE IMPLEMENTATION OF RADIOFREQUENCY VEIN ABLATION IN PATIENTS WITH VARICOSITY OF THE LOWER EXTREMITIES, TROPHIC ULCER COMPLICATIONS}

\section{Horbachevsky Ternopil National Medical University}

SUMMARY. The use of minimally invasive technology is a modern trend in the treatment of varicose disease of the lower extremities. However, there are certain restrictions for performing these operations against trophic ulcers.

The aim of the study - to provide a clinical rationale for the use of PRP and PRF technology for the treatment of trophic ulcers in patients with chronic venous insufficiency in the decompensation stage, with the aim of performing radiofrequency ablation of the veins. 
Огляди літератури, оригінальні дослідження, погляд на проблему, випадок з практики, короткі повідомлення

Material and Methods. Clinical studies of the use of PRP and PRF technologies for the treatment of trophic ulcers in 35 patients, the control group were 30 patients in whom trophic ulcers were treated with methyluracil or actovegin ointment. All patients underwent an ultrasound study of hemodynamics in superficial and deep veins, revealed the presence of vertical and horizontal reflux. Also, all patients were assessed for the status of trophic ulcers before and during treatment using the MEASURE system.

Results and Discussion. The use of PRP and PRF technology significantly enhances the processes of regeneration in a trophic ulcer, as evidenced by the reduction in the term of the appearance of granulation tissue, marginal epithelization, as compared with the control group of patients. There was a decrease in the area and depth of the wound defect by $23.1 \%, 37.4 \%$ and $79.9 \%$ by $5-6,8-9,12-14$ days compared with baseline data. Up to 8 days, most patients showed a change in the nature of the cytogram to the regenerative-inflammatory type. Dendrite and microbial bodies disappear. A characteristic sign in patients of the main group of patients is swallowed epithelization. In 24 (68.6 \%) patients, the trophic ulcer healed. The remaining 11 patients underwent trophic ulcer autodermoplasty during radiofrequency ablation of the veins. It should be noted that on average, the day of preoperative preparation of patients with trophic ulcers,

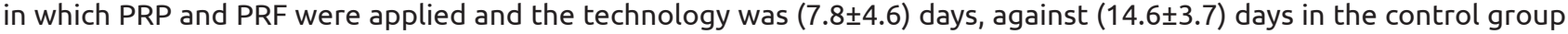
of patients. This made it possible to conduct a full-fledged RFA of varicose transforming veins with additional elimination of horizontal reflux in the area of trophic changes due to the use of sclerotherapy of insignificant perforant hives under ultrasound navigation.

Conclusions. 1. The use of PRP and PRF technology activates the processes of regeneration in chronic trophic ulcer, allowing to reduce the preoperative preparation of patients.

2. PRP and PRF technologists in the treatment of trophic ulcers in combination with low-impact operations (RFA and sclerotherapy) is a promising direction in the treatment of patients with lower limb varicose veins in the decompensation stage.

KEY WORDS: varicose veins; trophic ulcers; PRP and PRF technology.

Отримано 8.05.2019 